\title{
Chicken Collagen from Law Market Value By-Products as an Alternate Source
}

\author{
Kumudini A. Munasinghe, ${ }^{1,2}$ Jurgen G. Schwarz, ${ }^{2}$ and Anthony K. Nyame ${ }^{3}$ \\ ${ }^{1}$ Department of Biological Sciences, Salisbury University, Salisbury, MD 21801, USA \\ ${ }^{2}$ Food Science and Technology Ph. D. Program, Department of Agriculture, Food and Resource Sciences, \\ University of Maryland Eastern Shore, Princess Anne, MD 21853, USA \\ ${ }^{3}$ Department of Natural Sciences, University of Maryland Eastern Shore, Princess Anne, MD 21853, USA
}

Correspondence should be addressed to Kumudini A. Munasinghe; kamunasinghe@salisbury.edu

Received 28 December 2013; Revised 24 July 2014; Accepted 2 August 2014; Published 17 August 2014

Academic Editor: Vassiliki Oreopoulou

Copyright (c) 2014 Kumudini A. Munasinghe et al. This is an open access article distributed under the Creative Commons Attribution License, which permits unrestricted use, distribution, and reproduction in any medium, provided the original work is properly cited.

\begin{abstract}
There has been much interest in investigating possible means of making collagen from underutilized chicken by-products and it will lead to an alternate source of collagen for use in various industries such as pharmaceuticals, cosmetics, biomedical materials, and the food industry. The objective of this research was to find methods to extract collagen from chicken skins and bones to compare the corresponding yield differences and analyze their properties. Collagen extracted by acetic acid, citric acid, alkali, one-step acetic acid and pepsin, and two-step acetic acid and pepsin extraction procedures was compared. Complete randomized design, Student's $t$-test, and Tukey's test were used to analyze the samples $(P<0.05)$. The recovered dry weights for the skin extractions were 6.1, 6.2, $5,38.7$, and $40.4 \%$ and those of bone extractions were $4.4,4.1,4.1,19.1$, and $20.6 \%$, respectively. Protein, fat, and inorganic material contents of collagen preparations for skin were $62.7 \%, 1.5 \%$, and $0.7 \%$ and for bone were $30.4 \%, 1.4 \%$, and $0.7 \%$, respectively. This study indicates that chicken by-products have high potential use as an alternate source of collagen.
\end{abstract}

\section{Introduction}

Collagen from wastes has increasingly been of interest due to the abundance of collagen in many by-products [1]. Instead of manufacturing pet food using those wastes, it is of interest to convert them to a high-protein food for human consumption [2]. Collagen has a wide range of applications in the leather and film industries, pharmaceuticals, cosmetics, biomedical materials, and food industries [3-7]. In the food industry, frankfurter casings and beverages are the products that use collagen the most. There are many cosmetic and biomedical products in the market today that contain collagen. These products include hand and body lotions, nail treatments, firming gels, wrinkle injections, eye pads, and anticancer treatments [8].

Collagen is the most abundant naturally occurring protein in the extracellular matrix and most abundant connective tissue in the animal kingdom [9]. Some studies showed that approximately $30 \%$ of total animal protein consists of collagen $[1,10]$. Collagen structured organs include tendons, skin, bones, blood vessels, and connective tissue sheaths surrounding muscle fibers [9]. Collagen has been found in low market value by-products of chicken processing industry, such as skin, bones, and cartilage [11-13]. The chicken processing industry is an important income generator and one of the fastest growing food industries in the United States.

However, little information regarding the collagen extraction from chicken has been reported. The objective of this research was to compare five different extraction methods of collagen from chicken skins and bones to provide more information about chicken collagen as an alternate source of collagen.

\section{Materials and Methods}

2.1. Raw Material Preparation. Material preparation was adopted from Kittiphattanabawon et al. [14]. Chicken skin and bone were placed separately in polyethylene bags and 
kept on ice with a solid/ice ratio of $1: 2$ and transported to the Center of Food Science and Technology, University of Maryland Eastern Shore. Skin samples were cut into small pieces $\left(0.5 \times 0.5 \mathrm{~cm}^{2}\right)$ and cleaned with tap water before storing at $-20^{\circ} \mathrm{C}$. Chicken bones were cut into small pieces and blended with a Waring blender (Fisher Scientific, Pittsburgh, PA, USA) until the pieces were $1-5 \mathrm{~mm}$ diameter and stored at $-20^{\circ} \mathrm{C}$ until used.

2.2. Pretreatment. Removal of noncollagenous proteins, fat, and inorganic matter was conducted according to the method described by Kittiphattanabawon et al. [14] with slight modifications. All procedures were conducted at $4^{\circ} \mathrm{C}$ with continuous stirring.

2.2.1. Removal of Noncollagenous Proteins. Noncollagenous protein was removed by constantly mixing the samples of skin and bone with $0.1 \mathrm{~N} \mathrm{NaOH}$ at a sample/alkali solution ratio of 1: $6(\mathrm{w} / \mathrm{v})$. The mixture was stirred for 6 hours. Every 2 hours, the alkali solution was changed. Then the sample was washed with distilled water, until the water was clear.

2.2.2. Removal of Fat Content. The deproteinated bone and skin samples were defatted with $10 \%$ butyl alcohol with a solid/solvent ratio of 1:6 (w/v). The mixture was stirred for 24 hours. Every 6 hours, the solvent was changed. Then the defatted samples were washed with distilled water three times.

2.2.3. Removal of Inorganic Compounds. Inorganic compounds were removed by soaking the defatted sample in a $0.1 \mathrm{~N} \mathrm{HCl}$ solution with a solid/solvent ratio of $1: 6(\mathrm{w} / \mathrm{v})$. The mixture was stirred for 24 hours. Then the sample was filtered through double layer cheese cloth and washed three times with distilled water [15].

\subsection{Comparative Studies on Different Collagen Extraction} Methods. Pretreated samples were used to compare different extraction methods including acetic acid, citric acid, alkali, one-step acid and pepsin extraction, and two-step acid and pepsin extraction. All procedures were conducted at $4^{\circ} \mathrm{C}$ with continuous stirring.

2.3.1. Extraction of Collagen Using Acetic Acid. The method of Kittiphattanabawon et al. [14] was used for extraction of collagen from the sample using acetic acid, with modifications. The minced samples were soaked in $0.5 \mathrm{M}$ acetic acid with a solid/solvent ratio of 1:6 (w/v) for 48 hours. Double layer cheese cloth was used to filter the sample and filtrates were used for further precipitation procedures.

2.3.2. Extraction of Collagen Using Citric Acid. The method developed by Sakai et al. [16] was used for extraction of collagen from samples using citric acid, with modifications. A sample was extracted with $0.5 \mathrm{M}$ citric acid solution at a sample/solution ratio of $1: 6(\mathrm{w} / \mathrm{v})$ for 48 hours. The dissolved collagen in citric acid was purified by dialysis in distilled water at $4^{\circ} \mathrm{C}$ and the extraction was subjected to further precipitation methods.
2.3.3. Extraction of Collagen Using Alkali. The method developed by Morimura et al. [15] was used for extraction of collagen from samples using $0.1 \mathrm{~N} \mathrm{NaOH}$. The alkali solution was prepared by diluting a $\mathrm{NaOH}$ solution with water to $\mathrm{pH}$ 12. Samples were stirred with $\mathrm{NaOH}$ with a sample solution ratio of $1: 6(\mathrm{w} / \mathrm{v})$ at $4^{\circ} \mathrm{C}$ for 48 hours. After extraction, the samples were filtered through double layer cheese cloth and the resulting extract was used for further investigations.

2.3.4. One-Step Acid and Pepsin Extraction Method. $0.5 \mathrm{M}$ acetic acid containing pepsin $(20 \mathrm{kU} / \mathrm{g}$, Sigma-Aldrich Corp., St. Louis, MO, USA) was used to soak defatted samples for 48 hours. The solid/solvent ratio was 1:6 (w/v). The mixture was filtered with double layer of cheese cloth and the filtrate collected for precipitation [17].

2.3.5. Two-Step Acid and Pepsin Extraction Method. Samples were soaked in $0.5 \mathrm{M}$ acetic acid with a solid to solvent ratio of 1: $6(\mathrm{w} / \mathrm{v})$ for 24 hours. Double layer of cheese cloth was used to filter the mixture and the filtrate was collected. The residue was reextracted by using the same procedure with $0.5 \mathrm{M}$ acetic acid containing pepsin $(20 \mathrm{kU} / \mathrm{g})$ with a solid/solvent ratio of $1: 6(\mathrm{w} / \mathrm{v})$ at $4^{\circ} \mathrm{C}$ for 24 hours. The mixture was filtered through double layer cheese cloth. Precipitation was conducted for combined filtrates [17].

2.4. Collagen Precipitation. The collagen extractions were precipitated according to the method described by Kittiphattanabawon et al. [14]. $\mathrm{NaCl}$ was used for the precipitation at a final concentration of $2.6 \mathrm{M}$, in the presence of $0.05 \mathrm{M}$ Tris(hydroxymethyl)aminomethane, $\mathrm{pH}$ 7.0. The precipitates were collected by centrifuging at $20,000 \times \mathrm{g}$ for $60 \mathrm{~min}$ at $4^{\circ} \mathrm{C}$ and the pellets were dissolved in $0.5 \mathrm{M}$ acetic acid. Samples were dialyzed against ten volumes of $0.1 \mathrm{M}$ acetic acid and distilled water.

2.5. Analytical Procedures. Analysis of organic and inorganic materials including fat content and protein content of freeze dried samples was conducted according to the methods described by Morimura et al. [15] with modifications.

2.5.1. Organic Materials. The organic materials were determined according to the method of AOAC, Method 923.03. $2.5 \mathrm{~g}$ of freeze dried sample was placed in a muffle furnace at $500^{\circ} \mathrm{C}$ overnight. Organic matter (\%) was calculated as the ratio of reduced weight over sample weight in the incineration:

$$
\begin{aligned}
& \% \text { inorganic matter weight } \\
& \qquad=\frac{g \text { of ash in sample }}{g \text { of freeze dried sample }} \times 100 .
\end{aligned}
$$

2.5.2. Fat Content. The fat content was determined according to the method of AOAC, Method 945.16. $2.5 \mathrm{~g}$ of freeze dried sample was placed in a predried porous ceramic extraction thimble and placed into a glass holding tube. The glass holding tube was inserted into the condenser of the Goldfish extraction apparatus and allowed to reflux overnight with 
petroleum ether. Petroleum ether was recovered until only fat remains in the beaker:

$$
\% \text { fat on dry weight basis }=\frac{g \text { of fat in sample }}{g \text { of dried sample }} \times 100 .
$$

2.5.3. Protein Content. The protein content was determined according to the AOAC Method 990.03. A LECO FP-528 nitrogen/protein determinator (LECO Co., St. Joseph, MI, USA) was used to determine the protein content of the sample following the manufacturer's instructions.

EDTA was used as the calibration standard and approximately $0.2 \mathrm{~g}$ of sample was incinerated to determine the amount of nitrogen in the exhaust gas. A factor of 6.24 was used to calculate the protein content of the sample.

2.5.4. Peptide Mapping of Collagen. The method developed by Saito et al. [18] was used to perform peptide mappings of collagen, with modifications. Sodium phosphate $(0.1 \mathrm{M}$, $0.1 \mathrm{~mL}, \mathrm{pH} 7.2)$ containing $0.5 \%(\mathrm{w} / \mathrm{v})$ SDS was used to dissolve the freeze dried samples $(0.2 \mathrm{mg})$. The reaction mixture was incubated at $37^{\circ} \mathrm{C}$ for $25 \mathrm{~min}$, at which point $10 \mu \mathrm{L}$ of V8 protease preparation in the same buffer containing $5 \mu \mathrm{g}$ of Staphylococcus aureus V8 protease (EC 3.4.21.19, SigmaAldrich Corp., St. Louis, MO, USA) was added and the sample incubated for another $5 \mathrm{~min}$ at $37^{\circ} \mathrm{C}$. The reaction mixture was boiled for $3 \mathrm{~min}$ to terminate the reaction. SDS-PAGE using gradient gel (4-20\%) was used to separate the peptides generated by the protease digestion. Peptide patterns were compared with acid-soluble type I calf skin collagen.

2.5.5. Hydroxyproline Content. The method developed by Bergman and Loxley [19] was used to analyze the hydroxyproline content in collagen with a slight modification. $5 \mathrm{~N}$ $\mathrm{HCl}$ acid was used to hydrolyze the samples at $110^{\circ} \mathrm{C}$ for 24 hours in an oil bath (Fisher Scientific, Pittsburgh, PA, USA). Activated carbon was used to clarify the hydrolysate followed by filtration through Whatman number 4 filter paper. The filtrate was neutralized with $10 \mathrm{~N}$ and $1 \mathrm{~N} \mathrm{NaOH}$ to obtain a $\mathrm{pH}$ of $6.0-6.5$. Isopropanol $(0.2 \mathrm{~mL})$ was added and mixed thoroughly after transferring the neutralized sample $(0.1 \mathrm{~mL})$ into a test tube. Oxidant solution $[0.1 \mathrm{~mL}$, mixture of $7 \%$ $(\mathrm{w} / \mathrm{v})$ chloramine $\mathrm{T}$ and acetate/citrate buffer, $\mathrm{pH} 6$ at a ratio of $1: 4(\mathrm{v} / \mathrm{v})]$ was added and mixed thoroughly. Ehrlich's reagent solution $[1.3 \mathrm{~mL}$, mixture of $2 \mathrm{~g}$ of p-dimethylaminobenzaldehyde in $3 \mathrm{~mL}$ of $60 \%$ perchloric acid $(\mathrm{w} / \mathrm{v})$ and isopropanol at a ratio of $3: 13(\mathrm{v} / \mathrm{v})]$ was added. The mixture was agitated and heated at $60^{\circ} \mathrm{C}$ for $25 \mathrm{~min}$ in a water bath (Fisher Scientific, Pittsburgh, PA, USA) and cooled for 23 min in running water. Absorbance was measured against water at $558 \mathrm{~nm}$. Hydroxyproline concentrations ranging from 10 to $60 \mathrm{ppm}$ were used as standard solutions.

2.6. Statistical Analysis. The data was analyzed using a complete randomized design (CRD) and Student's paired $t$-test. The differences between means were evaluated by using Tukey's test. CRD was performed for the collagen yield comparison study and two replicates were used for the analysis.
Paired $t$-test was used to see the differences in protein, fat, and inorganic materials contents between the raw material (skin/bone) and the corresponding collagen extract with three replicates. Further data analysis was performed using Statistix Analytical Program (Version 9, 1998) and differences were considered significant when $P$ value was less than 0.05 .

\section{Results and Discussion}

3.1. Proximate Analysis of Chicken Skin and Bone and Their Collagen. Pretreatment and extraction of chicken skin and bone could be enhanced by cutting them into small pieces prior to pretreatment. Sadowska et al. [20] found that the mincing and homogenization of fish skin had a crucial influence on the yield of collagen. They achieved the largest percentage of collagen extracted (90\%) by treating minced homogenized skins rather than using whole skins (20 to $40 \%)$.

After conducting several preliminary studies, $120 \mathrm{~g}$ chicken skin/bone sample per $1000 \mathrm{~mL}$ beaker was used for the collagen extraction procedure for this study. The average protein, fat, and inorganic material contents of chicken skin, prior to pretreatment, were $22.6,31.6$, and $1.2 \%$ and those of collagen preparation from skin were $62.7,1.5$, and $0.7 \%$, dry weight basis. The average initial protein, fat, and inorganic material contents of the chicken bone prior to pretreatment were $24.4,7.6$, and $6.4 \%$ and those of collagen preparation from bone were $30.4,1.4$, and $0.7 \%$, dry weight basis.

\subsection{Comparison of Different Extraction Procedures of Chicken Collagen}

3.2.1. Preliminary Experiments. Five different extraction procedures were conducted to extract chicken collagen including acetic acid, citric acid, sodium hydroxide, one-step acid and pepsin, and two-step acid pepsin extraction procedure. The concentration of acetic acid to use was determined by conducting a yield optimization experiment. Collagen yields of the skin samples for $0.1 \mathrm{M}, 0.25 \mathrm{M}$, and $0.5 \mathrm{M}$ acetic acid were $7.9 \%, 8.1 \%$, and $8.4 \%$ wet weight, respectively. Therefore, $0.5 \mathrm{M}$ concentration of acetic acid was used for further extraction procedures. These results are in agreement with Zhou and Regenstein [21] who found that the collagen yield was increased gradually when acetic acid concentration was increased up to a concentration of $0.5 \mathrm{~mol} / \mathrm{L}$. Further, the same study showed that additional increases in the acetic acid concentration above $0.5 \mathrm{~mol} / \mathrm{L}$ increased the yield only slightly.

Morimura et al. [15] used an alkali extraction procedure to extract collagen from the spine of yellowtail fish and pig skin. In their study the alkali solution was prepared using $\mathrm{NaOH}$ after dissolving it in distilled water until the $\mathrm{pH}$ was adjusted to 12 . The extraction was conducted at $60^{\circ} \mathrm{C}$ with a rotary shaker for 1 hour. In preliminary experiments conducted for this study, chicken collagen could not be extracted at $60^{\circ} \mathrm{C}$. The denaturation temperature for chicken collagen was estimated to be $38^{\circ} \mathrm{C}$ by Sakai et al. [16]. The temperature of $60^{\circ} \mathrm{C}$ probably denatures the collagen protein in chicken so 
TABLE 1: Collagen yields extracted from the chicken skin and bone using different extraction procedures.

\begin{tabular}{lcc}
\hline Types of extraction & $\begin{array}{c}\text { Average* skin collagen } \\
\text { preparation yield \% }\end{array}$ & $\begin{array}{c}\text { Average* bone collagen } \\
\text { preparation yield \% }\end{array}$ \\
\hline Acetic acid & $6.1 \pm 1.0^{\mathrm{a}}$ & $4.4 \pm 0.5$ \\
Citric acid & $6.2 \pm 0.1$ & $4.1 \pm 0.7$ \\
Sodium hydroxide & $5.0 \pm 2.1$ & $4.1 \pm 1.0$ \\
One-step acid \& pepsin & $38.7 \pm 0.4$ & $19.1 \pm 3.0$ \\
Two-step acid \& pepsin & $40.4 \pm 0.8$ & $20.6 \pm 2.9$ \\
\hline
\end{tabular}

mean of four observations \pm SD.

* the average (arithmetic mean) of four observations.

that it becomes insoluble. Conducting the alkali extraction of chicken collagen at $4^{\circ} \mathrm{C}$ became successful.

In the fourth and fifth extraction procedures, pepsin was used to extract acid insoluble collagen. The one-step acid and pepsin extraction procedure was conducted for 48 hours and pepsin $(20 \mathrm{kU} / \mathrm{mg})$ was added to the mixture at the beginning. In the two-step acid and pepsin extraction procedure, the sample was first stirred with $0.5 \mathrm{M}$ acetic acid for 24 hours to remove acid-soluble collagen and the residue was reextracted by using the same procedure with $0.5 \mathrm{M}$ acetic acid containing pepsin $(20 \mathrm{kU} / \mathrm{g})$ for another 24 hours.

3.2.2. Comparison of Yields for Different Extraction Procedures of Chicken Collagen. Chicken skin and bone were not completely digested with acetic, citric, and $\mathrm{NaOH}$ extraction methods. These results were in agreement with Jongjareonrak et al. [22], who reported the incomplete solubilization of bigeye snapper skin in $0.5 \mathrm{M}$ acetic acid. The pepsin digestion procedures gave a complete digestion for chicken skin and no intact skin was left with pepsin after 48-hour digestion. Table 1 shows that the percentages of average skin collagen yield recovery for acetic acid, citric acid, $\mathrm{NaOH}$, one-step acid and pepsin, and two-step acid and pepsin extraction methods for skin collagen preparations were 6.1, 6.2, 5, 38.7, and 40.4\% dry weight, respectively. The percentages of bone collagen preparation yields with the same extraction procedures were $4.4,4.1,4.1,19.1$, and $20.6 \%$ dry weight, respectively (Table 1). Pepsin extractions recovered the highest amounts of collagen, over 38\% for skin and 19\% for bone (Table 1). Nalinanon et al. [17] suggested that swollen skin which was treated with acetic acid is possibly made porous and enhances pepsin digestion. These results suggest that more molecular crosslinks between collagen and other components can be broken by the additional digestion with pepsin.

Hickman et al. [23] reported that cross-linked molecules at the telopeptide region were cleaved by pepsins without damaging the integrity of the triple helix of collagen. Results in this study are in agreement with Nalinanon et al. [17], who showed the highest yield (65\%) of bigeye snapper skin was obtained when the skin was extracted with pepsin. Further, yield of the one-step acid and pepsin extraction of this study was a little lower than that of two-step acid and one-step pepsin extraction.

Moreover, Morimura et al. [15] explained that some materials derived from livestock or fishery waste tend to maintain

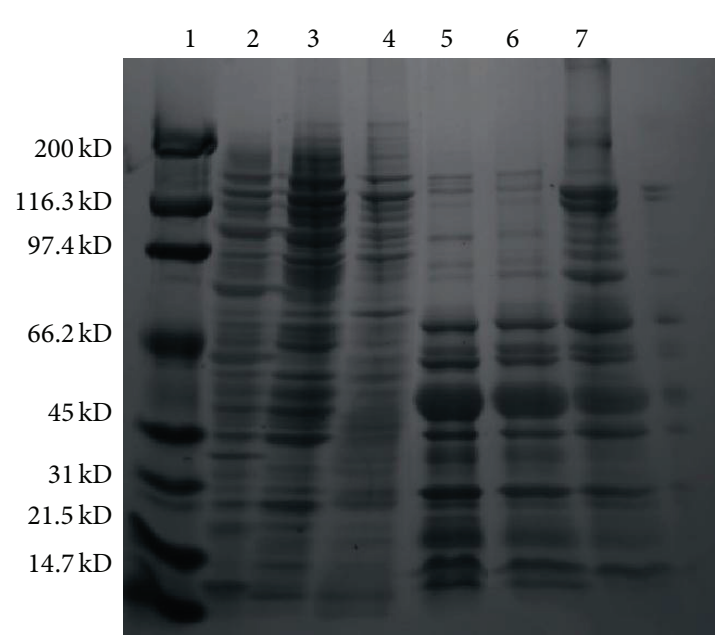

FIGURE 1: Peptide map of Staphylococcus aureus V8 for chicken skin collagen: (1) molecular weight marker, (2) calf skin collagen, (3) acetic acid extracted collagen, (4) citric acid extracted collagen, (5) one-step acid and pepsin extracted collagen, (6) two-step acid and pepsin extracted collagen, and (7) alkali extracted collagen.

odor characteristics of their source. This would limit the use of these materials or it would be necessary to mask the odor by the addition of fragrance. However, the chicken collagen extracted during this study did not have an objectionable odor.

3.3. Peptide Mapping. Peptide maps of collagens digested by Staphylococcus aureus V8 protease were compared with those of calf skin collagen type I and were examined by SDS-PAGE (gradient gel $4 \%-20 \%$ ) as shown in Figure 1. Electrophoresis patterns were analyzed after staining the sample with coomassie blue. The pattern of acetic acid and citric acid extracted chicken collagen was similar to that of acid extracted type I calf skin collagen. $\mathrm{NaOH}$ extracted collagen also showed some similarities to acid extracted calf collagen. Acid extracted collagen degraded with V8 protease showed a larger number of high molecular weight bands than molecular weights of pepsin extractions. The electrophoretic pattern of pepsin digested collagen showed more bands of low molecular weights smaller than $66.2 \mathrm{kDa}$. This result suggests that molecular components of acid extracted calf skin collagen had a similar tolerance to acid extracted chicken collagen 
for the digestion using V8 protease. Kittiphattanabawon et al. [14] suggested that molecular cross-linked components of acid extracted calf skin collagen were more tolerant to digestion by V8 than pepsin extracted collagen. VercaigneMarko et al. [24] found that V8 protease exhibits a high degree of specificity for glutamic acid and aspartic acid residues of peptides. Therefore, chicken skin collagen might contain glutamic acid and aspartic acid residues similar to those in the collagen from the calf skin.

3.4. Hydroxyproline Content. The hydroxyproline contents of the chicken skin collagen for acetic acid, citric acid, $\mathrm{NaOH}$, one-step acid and pepsin, and two-step acid and pepsin extractions were $5.9,5.9,5.8,5.8$, and $5.8 \mathrm{mg} / \mathrm{g}$, respectively. Similar results were expected for all extractions because chicken skin was used for all extraction procedures. Nalinanon et al. [17] found that the total hydroxyproline content of collagen extracted from the skin of bigeye snapper using pepsin changed with different extracting times and was $5.3 \mathrm{mg} / \mathrm{g}$ at $20 \mathrm{kU} / \mathrm{g}$ pepsin extraction for 24 -hour and $8.06 \mathrm{mg} / \mathrm{g}$ for 48 -hour extraction time. It was noted that the hydroxyproline content of most collagen in cattle and pig was 13 to $14 \mathrm{mg} / \mathrm{g}$ [25]. It has been shown that the total hydroxyproline content of bovine vitreous (the clear gel that fills the space between the lens and the retina of the eyeball) was $9.2 \mathrm{mg} / \mathrm{g}$ [26]. The same study showed that hydroxyproline concentration increased with age in bovine eyes. Therefore, broiler skin collagen may not have high hydroxyproline contents because of the shorter life cycle of the broiler chicken.

\section{Conclusions}

Pretreatment procedures were conducted to remove fat and minerals and were successful as indicated by a low fat and mineral content in the final collagen extractions. The skin collagen yields recovered from acetic acid, citric acid, alkali, one-step acid and pepsin, and two-step acetic acid and pepsin extractions were $6.1,6.2,5,38.7$, and $40.4 \%$ dry weight, respectively. The percentages of bone collagen yield recovered with the same extraction procedures were 4.4, 4.1, 4.1, 19.1, and $20.6 \%$ wet weight, respectively. Methods employing pepsin extraction after preswelling of chicken skin and bone with acetic acid gave the highest yields.

The chicken collagen extracted during this study was light in color and had no objectionable odor. Peptide mapping of acid solubilized chicken collagen gave results similar to acid solubilized calf skin collagen with the digestion of Staphylococcus aureus V8 protease. Therefore, the amount of glutamic and aspartic acid residues in chicken collagen might be similar to calf skin collagen.

The hydroxyproline content of samples from all five extractions ranged from 5.8 to $5.9 \mathrm{mg} / \mathrm{g}$ and it was less than hydroxyproline contents of bovine and porcine $(13-14 \mathrm{mg} / \mathrm{g}$ ). Collagen extracted from the chicken by-products may reduce the waste generated from the processing plants and also chicken collagen could be used as an alternate source of collagen for other industries as well.

\section{Conflict of Interests}

The authors declare that there is no conflict of interests regarding the publication of this paper.

\section{Acknowledgments}

This work was supported by Evans-Allen project. The authors thank Matthew Whittaker for his assistance to make this research a success. Also, the authors extend their thanks to Dr. Harter-Dennis at University of Maryland Eastern Shore for helping with statistical analysis and Dr. Mark Holland at Salisbury University for reviewing the paper.

\section{References}

[1] J. H. Muyonga, C. G. B. Cole, and K. G. Duodu, "Characterisation of acid soluble collagen from skins of young and adult Nile perch (Lates niloticus)," Food Chemistry, vol. 85, no. 1, pp. 81-89, 2004.

[2] P. Montero, F. Jimenez-Colmenero, and J. Borderias, "Effect of $\mathrm{pH}$ and the presence of $\mathrm{NaCl}$ on some hydration properties of collagenous material from trout (Salmo irideus Gibb) muscle and skin," Journal of the Science of Food and Agriculture, vol. 54, pp. 137-146, 1991.

[3] L. L. Hood, "Collagen in sausage casings," in Advances in Meat Research, pp. 109-129, Pearson. Nostrand Reinhold, New York, NY, USA, 4th edition, 1987.

[4] L. Slade and H. Levine, Polymer-Chemical Properties of Gelatin in Foods. Advances in Meat Research Collagen as Food, Nostrand Reinhold, New York, NY, USA, 1987.

[5] E. N. Marcel, Collagen, CRC Press, Boca Raton, Fla, USA, 1988.

[6] J. F. Cavallaro, P. D. Kemp, and K. H. Kraus, "Collagen fabrics as biomaterials," Biotechnology and Bioengineering, vol. 43, no. 8, pp. 781-791, 1994.

[7] F. Hassan and P. M. Sherief, "Role and application of fish collagen,” Seafood Export Journal, vol. 25, pp. 19-24, 1994.

[8] R. F. Diegelmann, “Collagen Metabolism,” Wounds, vol. 13, no. 5, pp. 177-182, 2001.

[9] E. A. Foegeding, T. C. Linier, and H. O. Hultin, "Characteristics of edible muscle tissues," in Food Chemistry, O. R. Fennema, Ed., pp. 879-942, Marcel Dekker, New York, NY, USA, 3rd edition, 1996.

[10] W. A. Bough, W. L. Brown, J. D. Porsche, and D. M. Doty, "Utilization of collagenous by-products from the meat packing industry: production of single-cell protein by the continuous cultivation of Bacillus megaterium," Applied Microbiology, vol. 24, no. 2, pp. 226-235, 1972.

[11] A. Maier and R. Mayne, "Connective-tissue macromolecules in Golgi chicken tendon organs and at their interface with muscle fibers and adjoining tendinous structures," The American Journal of Anatomy, vol. 188, no. 3, pp. 239-248, 1990.

[12] T. Yada, M. Arai, S. Suzuki, and K. Kimata, "Occurrence of collagen and proteoglycan forms of type IX collagen in chick embryo cartilage: Production and characterization of a collagen formspecific antibody," The Journal of Biological Chemistry, vol. 267, pp. 1265-1270, 1992.

[13] G. S. Mittal, "Meat in emulsion type sausages-an overview," Journal of Food, Agriculture and Environment, vol. 3, pp. 101108, 2005. 
[14] P. Kittiphattanabawon, S. Benjakul, W. Visessanguan, T. Nagai, and M. Tanaka, "Characterisation of acid-soluble collagen from skin and bone of bigeye snapper (Priacanthus tayenus)," Food Chemistry, vol. 89, no. 3, pp. 363-372, 2005.

[15] S. Morimura, H. Nagata, Y. Uemura, A. Fahmi, T. Shigematsu, and K. Kida, "Development of an effective process for utilization of collagen from livestock and fish waste," Process Biochemistry, vol. 37, no. 12, pp. 1403-1412, 2002.

[16] R. Sakai, S. Ikeda, and T. Isemura, "Soluble collagen of chicken leg tendon; its denaturation temperature and hydrodynamic properties," Chemical Society of Japan, vol. 40, pp. 2890-2894, 2003.

[17] S. Nalinanon, S. Benjakul, W. Visessanguan, and H. Kishimura, "Use of pepsin for collagen extraction from the skin of bigeye snapper (Priacanthus tayenus)," Food Chemistry, vol. 104, no. 2, pp. 593-601, 2007.

[18] M. Saito, N. Kunisaki, N. Urano, and S. Kimura, "Collagen as the major edible component of sea cucumber (Stichopus japonicus)," Journal of Food Science, vol. 67, no. 4, pp. 1319-1322, 2002.

[19] I. Bergman and R. Loxley, “Two improved and simplified methods for the spectrophotometric determination of hydroxyproline," Analytical Chemistry, vol. 35, no. 12, pp. 1961-1965, 1963.

[20] M. Sadowska, I. Kołodziejska, and C. Niecikowska, "Isolation of collagen from the skins of Baltic cod (Gadus morhua)," Food Chemistry, vol. 81, no. 2, pp. 257-262, 2003.

[21] P. Zhou and J. M. Regenstein, "Determination of total protein content in gelatin solutions with the Lowry or Biuret assay," Journal of Food Science, vol. 71, no. 8, pp. C474-C479, 2006.

[22] A. Jongjareonrak, S. Benjakul, W. Visessanguan, and M. Tanaka, "Isolation and characterization of collagen from bigeye snapper (Priacanthus macracanthus) skin," Journal of the Science of Food and Agriculture, vol. 85, no. 7, pp. 1203-1210, 2005.

[23] D. Hickman, T. J. Sims, C. A. Miles, A. J. Bailey, M. de Mari, and M. Koopmans, "Isinglass/collagen: denaturation and functionality," Journal of Biotechnology, vol. 79, no. 3, pp. 245-257, 2000.

[24] D. Vercaigne-Marko, E. Kosciarz, N. Nedjar-Arroume, and D. Guillochon, "Improvement of Staphylococcus aureus-V8-protease hydrolysis of bovine haemoglobin by its adsorption on to a solid phase in the presence of SDS: peptide mapping and obtention of two haemopoietic peptides," Biotechnology and Applied Biochemistry, vol. 31, no. 2, pp. 127-134, 2000.

[25] R. E. Neuman and M. A. Logan, "The determination of hydroxyproline," The Journal of Biological Chemistry, vol. 184, no. 1, pp. 299-306, 1950.

[26] P. N. Bishop, M. V. Crossman, D. McLeod, and S. Ayad, "Extraction and characterization of the tissue forms of collagen types II and IX from bovine vitreous," Biochemical Journal, vol. 299, no. 2, pp. 497-505, 1994. 

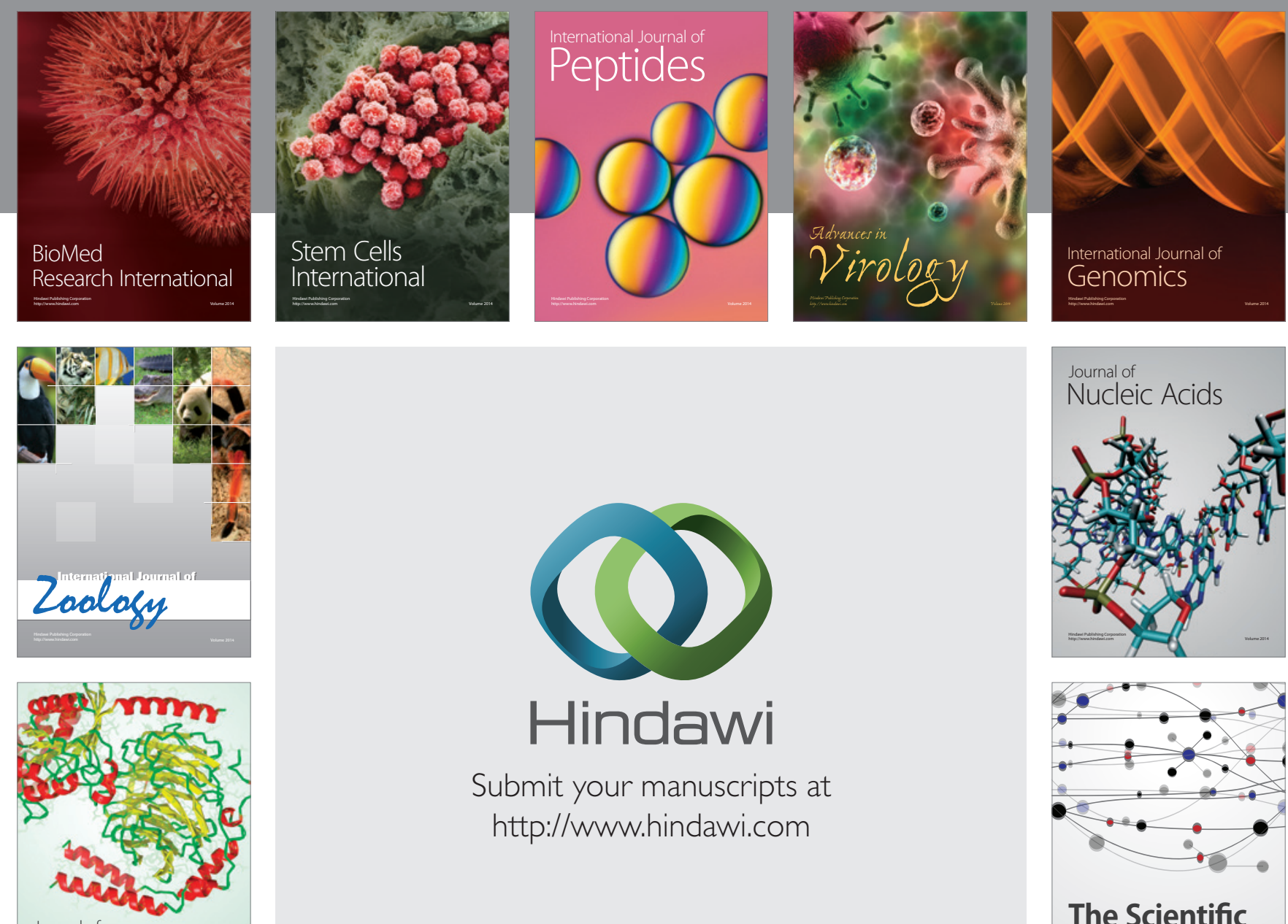

Submit your manuscripts at

http://www.hindawi.com

Journal of
Signal Transduction
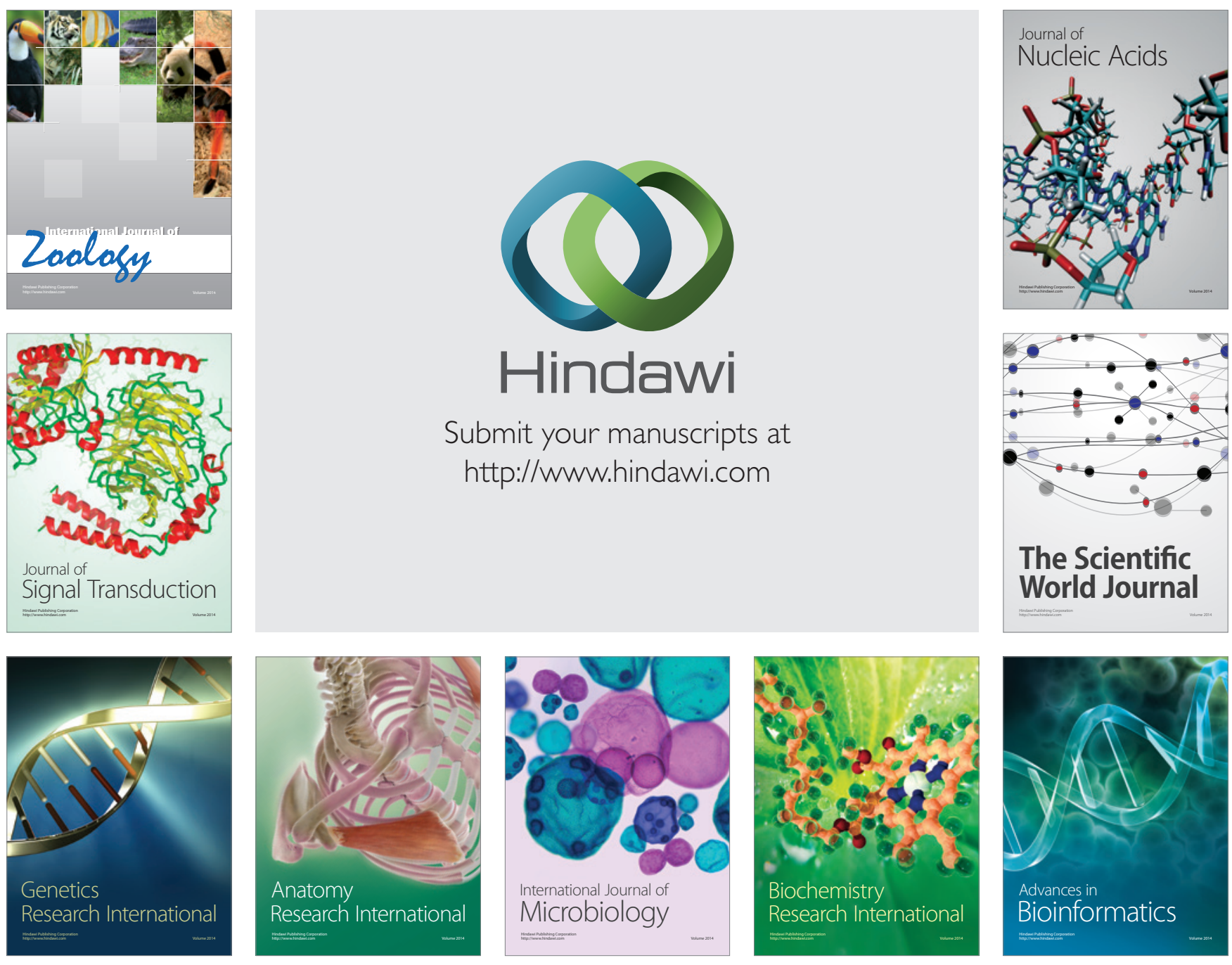

The Scientific World Journal
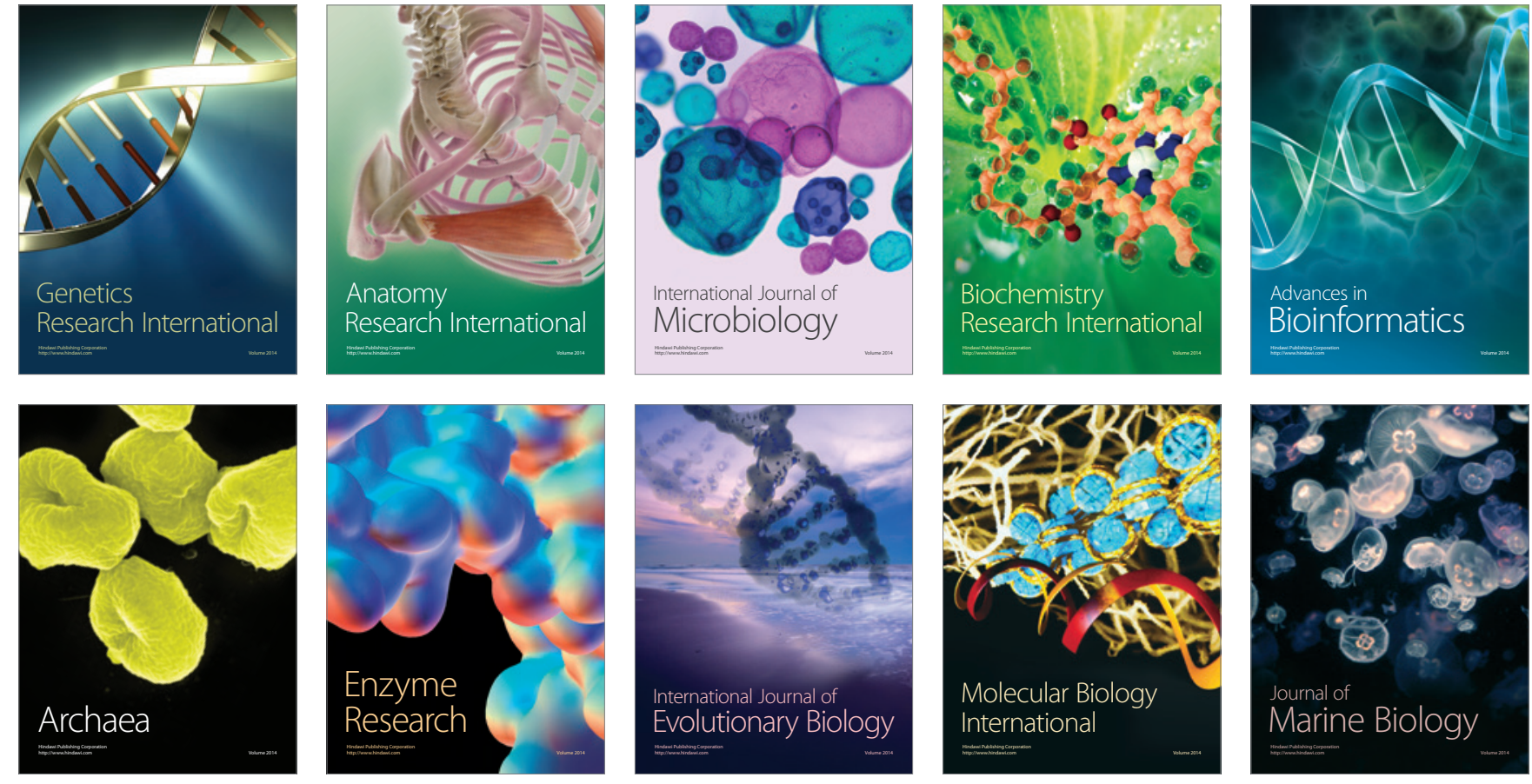